\title{
Geochemical fingerprints and controls in the sediments of an urban river: River Manzanares, Madrid (Spain)
}

\author{
Eduardo de Miguel $^{\mathrm{a}, *}$, Susanne Charlesworth ${ }^{\mathrm{b}}$, Almudena Ordóñez ${ }^{\mathrm{c}}$, Eduardo Seijas ${ }^{\mathrm{a}}$ \\ "Grupo de Geoquimica Ambiental, E.T.S.I Minas Madrid, Rios Rosas 21, 28003 Madrid, Spain \\ beparment of Geography, Coventry University, Priory Street, Caventry, CV'5 IFB, UK \\ 'E.T.S.I. Minas Oviedo, University of Oviedo, Independencia 13,33004 Oviedo. Spain
}

Received 5 January 2004; received in revised form 29 June 2004; accepted 28 July 2004

\begin{abstract}
The geochemical fingerprint of sediment retrieved from the banks of the River Manzanares as it passes through the City of Madrid is presented here. The river collects the effluent water from several Waste Water Treatment (WWT) plants in and around the city, such that, at low flows, up to $60 \%$ of the flow has been treated. A total of 18 bank-sediment cores were collected along the course of the river, down to its confluence with the Jarama river, to the south-east of Madrid. Trace and major elements in each sample were extracted following a double protocol: (a) "Total" digestion with $\mathrm{HNO}_{3}, \mathrm{HClO}_{4}$ and $\mathrm{HF}$; (b) "Weak" digestion with sodium acetate buffered to $\mathrm{pH}=5$ with acetic acid, under constant stirring. The digests thus obtained were subsequently analysed by ICP-AES, except for Hg which was extracted with aqua regia and sodium chloride-hydroxylamine sulfate, and analysed by Cold Vapour-AAS. X-ray diffraction was additionally employed to determine the mineralogical composition of the samples. Uni- and multivariate analyses of the chemical data reveal the influence of Madrid on the geochemistry of Manzanares' sediments, clearly manifested by a marked increase in the concentration of typically "urban" elements $\mathrm{Ag}, \mathrm{Cr}, \mathrm{Cu}$, $\mathrm{Pb}$ and $\mathrm{Zn}$, downstream of the intersection of the river with the city's perimeter. The highest concentrations of these elements appear to be associated with illegal or accidental dumping of waste materials, and with the uncontrolled incorporation of untreated urban runoff to the river. The natural matrix of the sediment is characterised by fairly constant concentrations of $\mathrm{Ce}$, $\mathrm{La}$ and $\mathrm{Y}$, whereas changes in the lithology intersected by the river cause corresponding variations in $\mathrm{Ca}-\mathrm{Mg}$ and $\mathrm{Al}-\mathrm{Na}$ contents. In the final stretch of the river, the presence of carbonate materials seems to exert a strong geochemical control on the amount of $\mathrm{Zn}$ and, to a lesser extent, $\mathrm{Cu}$ immobilised in the sediments. This fact suggests that a variable but significant proportion of both elements may be susceptible to reincorporation in the aqueous phase under realistic environmental conditions.
\end{abstract}




\section{Introduction}

The need to gain a better understanding of the behaviour of urban environments and the consequences of living within or close to a city's boundaries is clearly justified by the fact that cities have become the habitat where 2.7 billion people, or $47 \%$ of the total world population are currently housed. Furthermore, the (U.N. Population Division (UNPD) (2001)) estimates that nearly all the population growth in the next 30 years will be concentrated in the urban areas of the world. If this projection is accurate, 5.1 billion people will live in cities in 2030 and the percentage of urban population will accordingly increase to $60 \%$ of the world's total. If the statistical analysis is restricted to the more developed regions, it is estimated that the percentage of urban population in 2030 will reach $83.5 \%$, up from $76 \%$ in 2000 (U.N. Population Division (UNPD), 1996, 2001; World Bank, 2000).

With the growing interest in the rules that govern the fate of pollutants in urban environments, the sediments of urban rivers pose a particularly challenging scientific problem. As in natural environments, urban river sediments have a high potential for storage of trace elements. Unlike natural rivers, however, a large proportion of the trace element load contained in urban sediments is not associated with the original geologic parent material, but with the steady supply of trace elements, both dissolved and in particulate form, carried by treated and untreated urban waters. Changes in the aqueous environment to which urban sediments are exposed could result in the release of these trace elements that have accumulated over long periods of time. The linkage between the concentration of toxic elements in the sediment and ecosystem health explain the growing interest and the-consequent-rapid increase in scientific publications dealing with metals in fluvial sediments (Sutherland, 2000).

A further complication in the study of urban rivers arises from the fact that their hydrodynamic behaviour is sometimes profoundly altered as they run through a city. Urban rivers are often canalised, the flow of water is regulated, some sections of the river can be isolated and the water in them removed for cleaning operations, during which sediments are dredged and/or exposed to the atmosphere, etc. All these factors combine to make predictions about deposition and geochemical behav- iour of urban sediments quite uncertain. Within this context, River Manzanares constitutes an excellent example of an urban river with a strong anthropic control on its hydrodynamic behaviour and the geochemistry of its sediments. After passing through the city of Madrid, a large proportion of the water carried by River Manzanares is of urban origin and has entered the stream as discharge from five Waste Water Treatment (WWT) Plants that collect and treat the street runoff and domestic waste water (combined sewer system) of Madrid and a few nearby smaller towns. The river receives approximately $5.3 \times 10^{8} \mathrm{~m}^{3}$ of treated water from Madrid every year. The percentage of treated urban water in River Manzanares varies from approximately $20 \%$ in wet years to $60 \%$ in years with low precipitation,

\subsection{Description of River Manzanares}

The river rises at an altitude of $2160 \mathrm{~m}$ in the granite mountains of Sierra de Guadarrama, north of Madrid. For $90 \mathrm{~km}$, River Manzanares follows a southeast direction (Fig. 1), until it meets with the Jarama river shortly after exiting the urban perimeter of Madrid (pop, 3 million). Between the granitic Sierra and the city of Madrid, the Manzanares crosses Quaternary detrital materials, primarily gravel, sand and silt. Two major dams in the northern-most section of the river (Embalse de Santillana and El Pardo) control the flow of water arriving at the first of several weirs operated by Madrid's municipality. Four small streams between the first dam and Madrid and three downstream of the city - some of which flow only intermittently - contribute minor amounts of water to the River Manzanares. As it flows through the central part of the city, the river is canalised. Before and after this culverted section, small sections of the river banks are stabilised with large, angular boulders or rip-rap. South of Madrid, the River Manzanares flows through a landscape dominated by gypsiferous marls, clays and gypsum, intercalated with lenses of limestone.

\section{Methods and materials}

Eighteen sampling stations were positioned along the course of the River Manzanares (Fig. 1). The first four were located between the river's source and the 


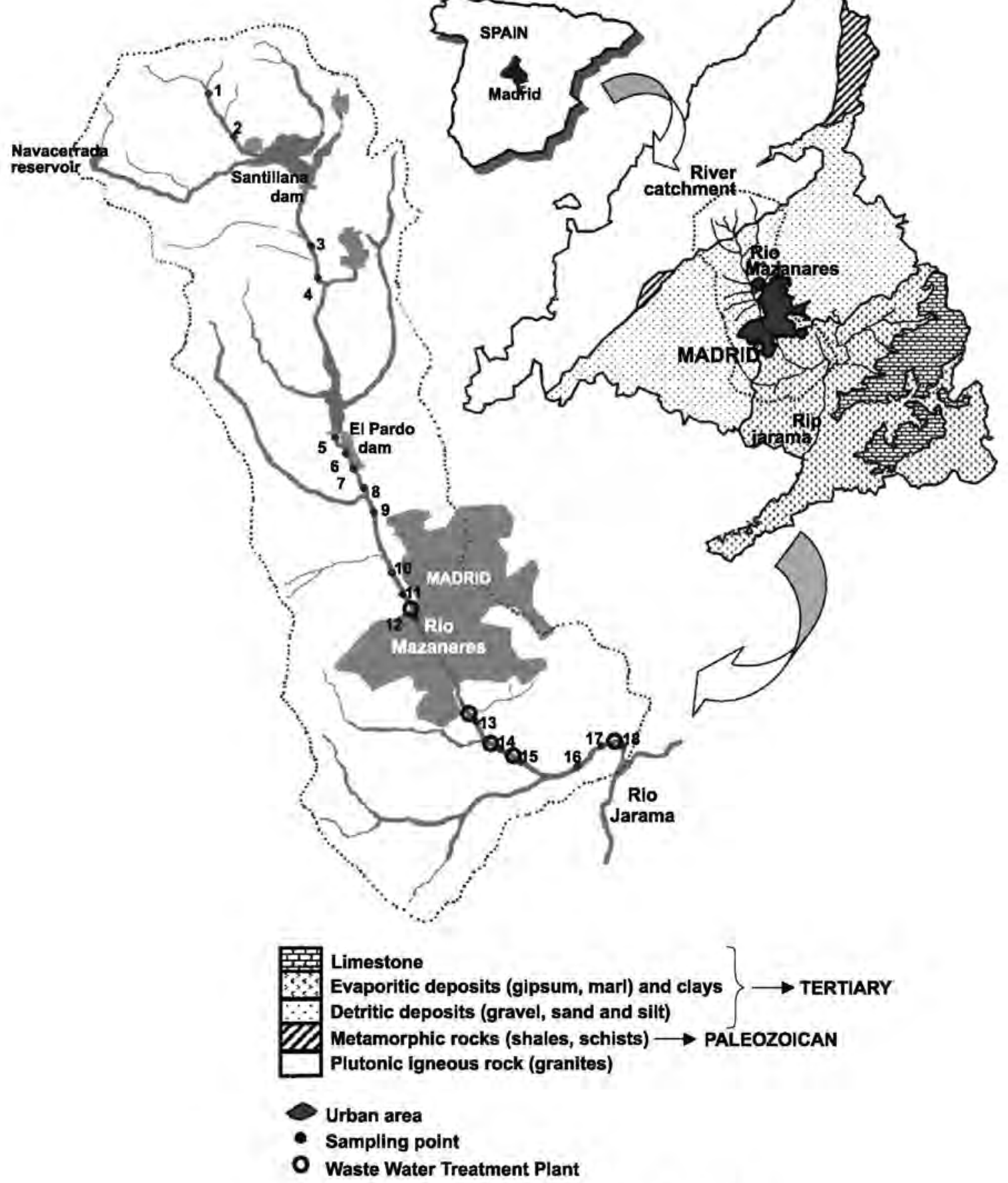

Fig. 1. River Manzanares basin and location of sampling points. 
Table 1

\begin{tabular}{|c|c|c|c|c|c|c|c|c|c|c|c|c|c|c|c|c|c|c|c|}
\hline Sample & 1 & 2 & 3 & 4 & 5 & 6 & 7 & 8 & 9 & 10 & 11 & 12 & 13 & 14 & 15 & 16 & 17 & 18 & Mean \\
\hline $\mathrm{Ag}$ & 1.3 & 1.1 & 0.25 & 0.06 & 3 & 2 & 2 & 2 & 2 & 4 & 5 & 0.51 & 16 & 7 & 5 & 4 & 9 & 9 & 4.1 \\
\hline $\mathrm{Al}$ & 93600 & 93500 & 87700 & 88000 & 81100 & 88800 & 61900 & 77600 & 81900 & 68600 & 72800 & 70300 & 67000 & 73000 & 65900 & 59700 & 65000 & 56900 & 75183 \\
\hline As & 17 & 18 & 4.2 & 4.2 & 25 & 9.7 & 57 & 34 & 23 & 36 & 9.9 & 10.1 & 39 & 27 & 31 & 25 & 10.2 & 29 & 23 \\
\hline $\mathrm{Ba}$ & 284 & 266 & 266 & 250 & 352 & 498 & 29 & 586 & 377 & 44 & 445 & 429 & 140 & 418 & 343 & 154 & 193 & 388 & 303 \\
\hline $\mathrm{Be}$ & 6 & 6 & 7 & 7 & 6 & 8 & 6 & 6 & 5 & 5 & 6 & 4 & 5 & 5 & 4 & 4 & 5 & 4 & 5.5 \\
\hline $\mathrm{Ca}$ & 8300 & 5200 & 6000 & 3500 & 6300 & 5400 & 10100 & 6200 & 8300 & 14200 & 4400 & 8800 & 27600 & 16600 & 82300 & 80200 & 31600 & 71100 & 22561 \\
\hline $\mathrm{Ce}$ & 139 & 183 & 126 & 104 & 148 & 158 & 136 & 193 & 182 & 115 & 185 & 47 & 135 & 142 & 68 & 131 & 203 & 138 & 141 \\
\hline Co & 5 & 4 & 5 & 5 & 6 & 6 & 9 & 5 & 5 & 6 & 5 & 5 & 8 & 5 & 9 & 6 & 6 & 8 & 6 \\
\hline $\mathrm{Cr}$ & 25 & 30 & 23 & 21 & 59 & 25 & 33 & 19 & 18 & 27 & 29 & 26 & 126 & 30 & 46 & 36 & 52 & 61 & 38 \\
\hline $\mathrm{Cu}$ & 11 & 12 & 42 & 49 & 27 & 29 & 144 & 19 & 31 & 55 & 44 & 49 & 347 & 64 & 93 & 62 & 94 & 100 & 71 \\
\hline $\mathrm{Fe}$ & 19100 & 20400 & 26000 & 20100 & 22100 & 27600 & 90800 & 19800 & 22000 & 29000 & 19500 & 22400 & 38400 & 23000 & 30000 & 21900 & 23400 & 26000 & 27861 \\
\hline $\mathrm{Hg}$ & 0.025 & 0.025 & 0.025 & 0.196 & 0.072 & 0.217 & 0.076 & 0.085 & 0.671 & 1.776 & 0.234 & 0.805 & 0.528 & 0.708 & 0.792 & 1.241 & 0.931 & 0.234 & 0.48 \\
\hline$K$ & 27200 & 25400 & 21900 & 21900 & 32800 & 27800 & 21100 & 28600 & 26900 & 26500 & 27700 & 27300 & 24700 & 27700 & 43800 & 24900 & 26900 & 22200 & 26961 \\
\hline $\mathrm{La}$ & 70 & 89 & 60 & 49 & 69 & 79 & 66 & 97 & 94 & 61 & 101 & 23 & 71 & 76 & 40 & 71 & 107 & 76 & 72 \\
\hline $\mathrm{Mg}$ & 5800 & 4500 & 5300 & 4400 & 4500 & 5800 & 7000 & 5000 & 6800 & 5900 & 5600 & 4100 & 14900 & 7000 & 11400 & 9800 & 7600 & 14600 & 7222 \\
\hline Mn & 359 & 305 & 399 & 396 & 503 & 578 & 1276 & 724 & 649 & 408 & 430 & 308 & 381 & 409 & 469 & 370 & 371 & 332 & 481 \\
\hline $\mathrm{Na}$ & 18200 & 17900 & 15000 & 13100 & 19200 & 15500 & 11700 & 16100 & 13500 & 12900 & 15500 & 15500 & 13700 & 16000 & 6400 & 10900 & 14300 & 10400 & 14211 \\
\hline $\mathrm{Ni}$ & 9.4 & 11 & 7.4 & 5.3 & 47 & 12 & 33 & 12 & 4.9 & 18 & 19 & 12 & 36 & 14 & 23 & 19 & 26 & 29 & 19 \\
\hline $\mathrm{P}$ & 639 & 737 & 1090 & 876 & 927 & 737 & 1297 & 812 & 850 & 1001 & 1040 & 913 & 1568 & 1432 & 992 & 1049 & 1618 & 1487 & 1059 \\
\hline $\mathrm{Pb}$ & 93 & 74 & 171 & 44 & 56 & 42 & 207 & 74 & 44 & 87 & 93 & 95 & 371 & 126 & 107 & 104 & 179 & 150 & 118 \\
\hline $\mathrm{Ti}$ & 1800 & 2000 & 1500 & 1500 & 2700 & 3100 & 2200 & 3300 & 3400 & 2700 & 3000 & 1800 & 2900 & 3100 & 3600 & 2700 & 3100 & 2900 & 2628 \\
\hline $\mathrm{v}$ & 28 & 28 & 28 & 29 & 28 & 33 & 29 & 26 & 25 & 28 & 23 & 24 & 44 & 29 & 57 & 32 & 26 & 39 & 31 \\
\hline Y & 37 & 36 & 28 & 24 & 30 & 32 & 26 & 31 & 29 & 23 & 29 & 20 & 26 & 27 & 17 & 26 & 31 & 25 & 28 \\
\hline $\mathrm{Zn}$ & 74 & 70 & 113 & 97 & 79 & 102 & 182 & 84 & 81 & 178 & 124 & 152 & 591 & 198 & 313 & 258 & 439 & 393 & 196 \\
\hline
\end{tabular}




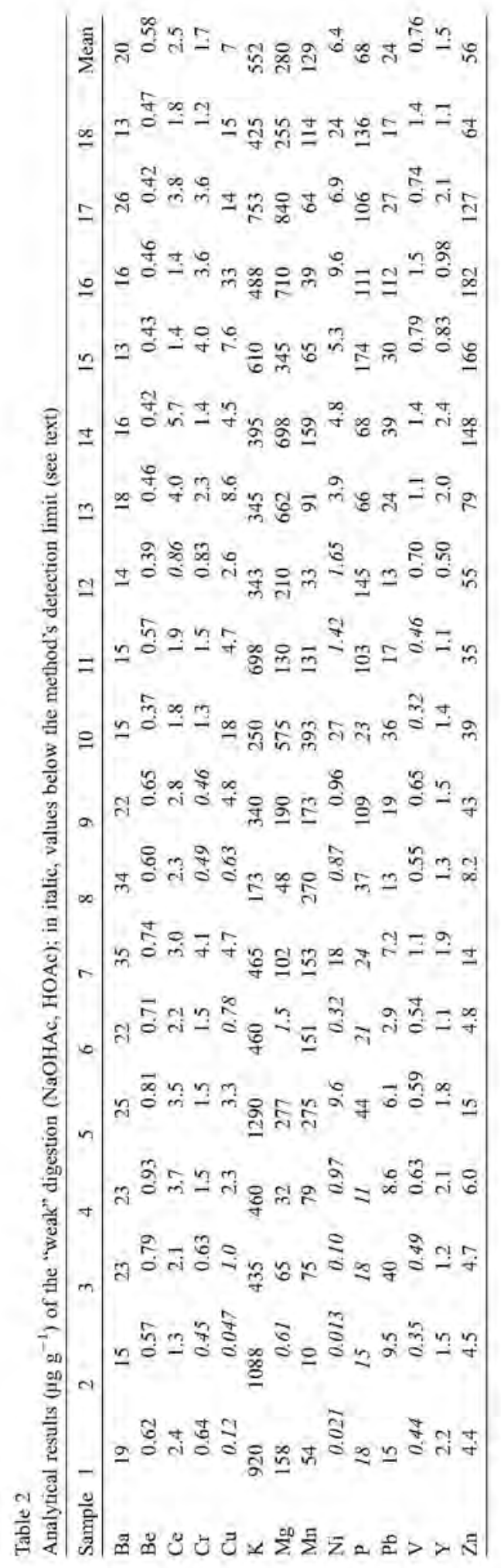

first major dam, El Pardo dam; seven between this dam and the first WWT plant; one directly before the culverted stretch of the river in the city of Madrid; one immediately downstream of the second, third and fourth WWT plants, respectively; two more between the fourth and fifth WWT plants; and a last one downstream of the fifth WWT plant and close to the confluence of the Manzanares with the Jarama river (Fig. 1).

Sediment cores were retrieved from the upper $20 \mathrm{~cm}$ of the river bank, a few centimeters below the water level (and thus representing material that is periodically exposed to the atmosphere in the Summer months and during low-flow episodes) with an Eijkelkamp ${ }^{\mathbb{B}}$ riverside auger or a piston sampler. The samples were then transferred to air-tight plastic bags and transported in a portable refrigerator to the laboratory. All samples were oven-dried at $50{ }^{\circ} \mathrm{C}$ for $48 \mathrm{~h}$, manually disaggregated and sieved to recover the $<50 \mu \mathrm{m}$ fraction (considered to represent the silt-clay fraction of the sediment). Three subsamples were subsequently separated for "total" and "weak" digestions, and for $\mathrm{Hg}$ analysis.

From the first subsample $1 \mathrm{~g}$ was transferred to a Teflon reactor where a mixture of $5 \mathrm{ml} \mathrm{HNO}_{3}(70 \% \mathrm{v}$ / v), $5 \mathrm{ml} \mathrm{HClO}_{4}(70 \% \mathrm{v} / \mathrm{v})$, and $10 \mathrm{ml} \mathrm{HF}(48 \% \mathrm{v} / \mathrm{v})$ was added. The solution was then heated to dryness in an open hot-plate, and the residue redissolved with $5 \mathrm{ml}$ $\mathrm{HCl}(36 \% \mathrm{v} / \mathrm{v})$ and $20 \mathrm{ml}$ MilliQ water. The resulting solution was filtered and transferred to a $100 \mathrm{ml}$ volumetric flask. This analytical protocol is assumed to dissolve the silicate matrix of the sample and thus yield a "total" digest.

A second $1 \mathrm{~g}$ subsample was subjected to a "weak" digestion with $1 \mathrm{M}$ sodium acetate ( $\mathrm{NaOHAc})$, buffered to $\mathrm{pH} 5$ with acetic acid (HOAc, 99.5\% v/ $v)$, under constant stirring for $5 \mathrm{~h}$. The solution thus obtained was filtered and transferred to a $25 \mathrm{ml}$ volumetric flask. This protocol coincides with the second step in Tessier's sequential extraction procedure (Tessier et al., 1979) and the "weak" digest is presumed to represent the fraction of the sediment that could become mobile and bioavailable under realistic environmental conditions.

Preparation of a third subsample for $\mathrm{Hg}$ analysis followed US Environmental Protection Agency's Method 7471A (US Environmental Protection Agency, 1994): $0.2 \mathrm{~g}$ of sediment was mixed with $5 \mathrm{ml}$ deionised water and $5 \mathrm{ml}$ aqua regia, and the solution 
was then heated for $2 \mathrm{~min}$ in a water bath at $95^{\circ} \mathrm{C}$. After cooling, $50 \mathrm{ml}$ deionised water and $15 \mathrm{ml} 5 \% \mathrm{KMnO}_{4}$ were added to the solution. The solution was then heated again for $30 \mathrm{~min}$, allowed to cool, $6 \mathrm{ml}$ of sodium chloride-hydroxylamine sulphate were added to the solution, and the volume was made up to $100 \mathrm{ml}$ with deionised water.

All samples were analysed for 17 trace elements and 6 major elements (Table 1) by Inductively Coupled Plasma-Atomic Emission Spectrometry (ICP-AES) while $\mathrm{Hg}$ concentrations were determined by Cold Vapour-Atomic Absorption Spectrometry (CV-AAS) at the Laboratory of Inorganic Analysis of the Spanish Geological Survey (IGME). Reagent blanks and standard reference materials, i.e. NIST SRM 2704, river sediment (Epstein et al., 1989), were used for quality control. The analytical results for $\mathrm{Ag}$, $\mathrm{As}, \mathrm{Al}, \mathrm{Ca}, \mathrm{Co}, \mathrm{Fe}, \mathrm{La}, \mathrm{Na}$ and $\mathrm{Ti}$ in the sodium acetate-acetic acid extraction were below the method's detection limit in more than $50 \%$ of all observations or did not pass the repeatability standards in the quality control guidelines, and were consequently omitted from the corresponding database (Table 2).

Analytical results below the method's detection limit (in italics in Table 1 and Table 2), when present in less than $50 \%$ of all the observations for a given variable, were substituted by the arithmetic mean of the three actual readings of the ICP-AES for that sample. For Mercury, however, the laboratory did not supply the original readings and observations below the detection limit were replaced with half the value of the detection limit.

Additionally, the mineral matrix of the samples was characterised by X-ray Diffraction (XRD), including preparation of oriented aggregates, ethyl- ene glycol swelling tests for smectite and thermal treatment for kaolinite.

\section{Description and interpretation of results}

Tables 1 and 2 show the results of the elemental analyses after the "total" and "weak" digestions, respectively. Results of the X-ray diffraction analyses are presented in Table 3 . Univariate analysis of the data for the "total" digestion shows, in the first place, the anomalous nature of samples 7 and 13. Sample 7. marked by high concentrations of total As and $\mathrm{Fe}$ (57 and $90800 \mu \mathrm{g} \mathrm{g}^{-1}$, respectively), was collected from a station where the section of the river becomes deep and narrow, creating a pool in which sediments accumulate preferentially. XRD analysis of the sample reveals the presence of pyrite in concentrations close to $10 \%$, a fact that would explain the elevated levels of total As and Fe. It is unclear whether the accumulation of pyrite is the result of illegal or accidental disposal of mining/industrial wastes, or whether it is associated with the transport and deposition, in this low-velocity reach, of sulphide materials found in mineral deposits and abandoned mining sites located upstream from station 7. Sample 13 was taken just downstream of the second WWT plant, which collects and treats urban runoff and domestic waste waters from Madrid's city centre. The highest concentrations of total $\mathrm{Ag}(16 \mu \mathrm{g}$ $\left.\mathrm{g}^{-1}\right), \mathrm{Cr}\left(126 \mu \mathrm{g} \mathrm{g}^{-1}\right), \mathrm{Cu}\left(347 \mu \mathrm{g} \mathrm{g}^{-1}\right), \mathrm{Pb}(371 \mu \mathrm{g}$ $\left.\mathrm{g}^{-1}\right)$ and $\mathrm{Zn}\left(591 \mu \mathrm{g} \mathrm{g}^{-1}\right)$ were found at this location. This elemental association is characteristic of urban particulate materials (soil and street dust), but also of discharges from WWT plants (Birch et al., 2001), sewage sludge produced in WWT plants, and of the

Table 3

Results of the X-ray diffraction analyses

\begin{tabular}{|c|c|c|c|c|c|c|c|c|c|c|c|c|c|c|c|c|c|c|}
\hline Sample & 1 & 2 & 3 & 4 & 5 & 6 & 7 & 8 & 9 & 10 & 11 & 12 & 13 & 14 & 15 & 16 & 17 & 18 \\
\hline$\%$ Quartz & 30 & 28 & 27 & 31 & 22 & 28 & 24 & 36 & 28 & 36 & 34 & 28 & 30 & 37 & 25 & 22 & 31 & 33 \\
\hline$\%$ Plagioclase & 31 & 23 & 16 & 19 & 28 & 16 & 12 & 13 & 14 & 13 & 11 & 10 & 17 & 16 & 6 & 11 & 19 & 10 \\
\hline$\% \mathrm{~K}$ Feldspar & 8 & 16 & 10 & 8 & 20 & 21 & 11 & 13 & 13 & 13 & 15 & 12 & 7 & 11 & 9 & 9 & 13 & 6 \\
\hline$\%$ Calcite & - & - & - & - & - & - & - & 3 & 3 & 3 & I & 15 & 5 & 3 & 20 & 17 & 6 & 18 \\
\hline \%Dolomite & 2 & 2 & 3 & - & 2 & 1 & 1 & 3 & 1 & 3 & 3 & 2 & 3 & 1 & 3 & 4 & 2 & 5 \\
\hline \%Phyllosilicate & 29 & 31 & 44 & 42 & 28 & 34 & 42 & 32 & 41 & 32 & 36 & 33 & 38 & 32 & 37 & 37 & 29 & 28 \\
\hline$\%$ Smectite & $=$ & - & - & r & 12 & 12 & 17 & 14 & 30 & 14 & 22 & 10 & 14 & 10 & 8 & 13 & 9 & 7 \\
\hline$\%$ Micá & 18 & 17 & 18 & 19 & 16 & 18 & 25 & 18 & 11 & 18 & 14 & 23 & 24 & 22 & 22 & 24 & 20 & 21 \\
\hline$\%$ Vermiculite & 11 & 14 & 26 & 14 & - & - & - & - & - & - & - & - & - & - & 7 & - & - & - \\
\hline$\%$ Kaolinite & - & - & - & 9 & - & 4 & - & - & - & - & - & - & - & - & - & - & - & - \\
\hline
\end{tabular}


Table $4 \mathrm{a}$

Comparative analysis of trace element concentration $\left(\mu \mathrm{g} \mathrm{g}^{-1}\right)$ in urban river sediments

\begin{tabular}{|c|c|c|c|c|c|c|c|c|c|c|}
\hline & & $\mathrm{Ag}$ & As & $\mathrm{Cr}$ & $\mathrm{Cu}$ & $\mathrm{Fe}(\%)$ & Mn & $\mathrm{Ni}$ & $\mathrm{Pb}$ & $\mathrm{Zn}$ \\
\hline River Henares, Spain ${ }^{a}$ & & & & $(97-180)$ & $(7-270)$ & $(0.8-3.16)$ & $(150-445)$ & & $(11-128)$ & $(17-1280)$ \\
\hline River Seine, France $^{b}$ & & & & & 84 & 2.91 & & & 162 & 429 \\
\hline & Upstream & & & & 15.1 & & & 40.9 & 120 & 343 \\
\hline \multirow[t]{2}{*}{ River Sowe, UK ${ }^{\mathrm{E}}$} & Urban area & & & & 47.9 & & & 164 & 411 & 786 \\
\hline & Downstream & & & & 18.6 & & & 103 & 234 & 496 \\
\hline Semarang, Indonesia ${ }^{d}$ & & & & & $(12.3-448)$ & & & & $(5.2-2666)$ & $(53.7-1257)$ \\
\hline Danube River, Austria ${ }^{e}$ & & & & & 43.5 & & & & 53.9 & 187 \\
\hline Tiber River, Italy ${ }^{\mathrm{F}}$ & & & & $(18.2-54.2)$ & $(13.3-45.5)$ & & & $(3.6-33.5)$ & $(12.4-43.1)$ & $(53.4-417.6)$ \\
\hline River Po, Italy ${ }^{g}$ & & & $(5.8-10.9)$ & $(118-233)$ & $(45.2-179.9)$ & $(4.5-5.2)$ & $(355-1159)$ & $(99-237)$ & $(39.3-71.8)$ & $(127-519)$ \\
\hline River Sherbourne $e^{\text {s }}$ & & & & & $(7.1-270)$ & & & $(30-843)$ & $(45.7-957)$ & $(114-1586)$ \\
\hline & & 4.1 & 23 & 38 & 71 & 2.9 & 481 & 19 & 118 & 196 \\
\hline River Manzanares & & $(0.1-16)$ & $(4.2-57)$ & $(18-126)$ & $(11-347)$ & $(1.9-9.1)$ & $(305-1276)$ & $(5-47)$ & $(42-371)$ & $(70-591)$ \\
\hline
\end{tabular}

In brackets: minimum-maximum values; in italic: arithmetic mean.

a Alaroón (1990).

${ }^{b}$ Estébe et al. (1997).

- Foster et al. (1996).

d Widianarko et al. (2000),

¿ Gundacker (2000).

${ }^{f}$ Minissi et al. (1998).

Eignati et al. (2003).

${ }^{h}$ Foster and Charlesworth (1996).

compost prepared with it (De Miguel et al., 1998). It is therefore possible that the elevated levels of "urban" elements in these sediments are associated with discharges from the WWT plant or, more likely, with the direct supply of untreated urban runoff to the river (Walker et al., 1999). This last hypothesis is supported by the proximity of the sampling station to an abandoned, illegal dump site whose effluents are suspected to reach the river course without entering the sewage system.

Although direct comparisons of the results of different investigations are complicated by the dispar-

Table $4 \mathrm{~b}$

Comparative analysis with toxicological reference values for river sediments (units in $\mu \mathrm{g} \mathrm{g}^{-1}$ )

\begin{tabular}{|c|c|c|c|c|c|c|c|c|}
\hline \multirow[t]{2}{*}{ Element } & \multicolumn{3}{|l|}{ US DOE ${ }^{a}$} & \multicolumn{2}{|l|}{ Canadian $\mathrm{EQG}^{\mathrm{b}}$} & \multirow{2}{*}{$\begin{array}{l}\frac{\text { US EPA }^{c}}{\text { Toxicity }} \\
\text { reference } \\
\text { value }\end{array}$} & \multirow{2}{*}{$\begin{array}{l}\text { Ontario } \mathrm{MOE}^{\mathrm{d}} \\
\text { Lowest } \\
\text { effect } \\
\text { level }\end{array}$} & \multirow{2}{*}{$\begin{array}{l}\text { Manzanares } \\
\text { Arithmetic } \\
\text { mem }\end{array}$} \\
\hline & $\begin{array}{l}\text { Threshold effect } \\
\text { concentration }\end{array}$ & $\begin{array}{l}\text { Probable effect } \\
\text { concentration }\end{array}$ & $\begin{array}{l}\text { High no effect } \\
\text { concentration }\end{array}$ & $\begin{array}{l}\text { Interim sediment } \\
\text { quality guideline }\end{array}$ & $\begin{array}{l}\text { Probable } \\
\text { effect } \\
\text { level }\end{array}$ & & & \\
\hline $\mathrm{Ag}$ & & & & & & 4.5 & 0.5 & 4.1 \\
\hline Al & & 58030 & 73160 & & & 14000 & & 75183 \\
\hline As & 12.1 & 57 & 92.9 & 5.9 & 17 & 6 & 6 & 22.8 \\
\hline $\mathrm{Ba}$ & & & & & & 20 & & 303 \\
\hline $\mathrm{Co}$ & & & & & & & 50 & 6 \\
\hline $\mathrm{Cr}$ & 56 & 159 & 312 & 37.3 & 90 & 26 & 26 & 38 \\
\hline $\mathrm{Cu}$ & 28 & 77.7 & 54.8 & 35.7 & 197 & 16 & 16 & 71 \\
\hline $\mathrm{Hg}$ & & & & 0.170 & 0.486 & & 0.2 & 0.480 \\
\hline $\mathrm{Ni}$ & 39.6 & 38.5 & 37.9 & & & 16 & 16 & 19 \\
\hline $\mathrm{Pb}$ & 34.2 & 396 & 68.7 & 35 & 91.3 & 31 & 31 & 118 \\
\hline $\mathrm{Zn}$ & 159 & 1532 & 541 & 123 & 315 & 110 & 120 & 196 \\
\hline
\end{tabular}

a Jones et al. (1997).

b Environment Canada (2002).

¿ US Environmental Protection Agency (1999).

d Ontario Ministry of Environment and Energy (1998). 
ity in sampling protocols, digestion procedures of the samples, and the intensity of industrial discharges into the river, the concentrations of trace elements in the sediments of the Manzanares seem to fall in the same range as those found in other urban rivers, i.e. the Seine, Sherbourne, Henares, Semarang, Danube, Tiber, and Po (Table 4a). However, when compared with effects-based toxicological levels the situation is quite different (Table 4b). The mean concentrations determined for the River Manzanares are higher than Ontario's Lowest Effeet Levels and than the US EPA's Toxicity Reference Values for all trace elements, with the exceptions of $\mathrm{Co}$ and $\mathrm{Ag}$. Similarly, all of the Canadian Sediment Quality Guidelines are exceeded and the average concentrations of $\mathrm{As}$ and $\mathrm{Pb}$ in the Manzanares are even higher than the respective Probable Effect Levels (PELs), with the mean $\mathrm{Hg}$ concentration being almost identical to the corresponding PEL. Lastly, the Threshold Effect Concentrations defined by the U.S, Department of Energy (U.S, DOE) for $\mathrm{As}, \mathrm{Cu}, \mathrm{Pb}$ and $\mathrm{Zn}$ are surpassed by the average concentration of these same elements in the sediments of the Manzanares; for $\mathrm{Cu}$ and $\mathrm{Pb}$ even the high $\mathrm{No}$ Effect Concentrations are exceeded. A comparison with only those samples retrieved from stations within or downstream of Madrid is even more unfavourable, all of which seems to indicate that the levels of trace elements found in the sediments of river Manzanares might result in adverse effects on the aquatic ecosystems associated with this river, especially after it receives urban waters originating in Madrid.

In order to describe better and interpret the results of the multiple chemical variables analysed by ICPAES and AAS, a number of multivariate statistical techniques were employed, i.e. Hierarchical Cluster Analysis, Direct Partition (K-means Cluster Analysis), and Factor Analysis. Cluster Analysis of observations for the "total" digest reveals three main groups of samples (Fig. 2). All the sediment cores collected upstream of the urban perimeter of Madrid (samples $1-9$ ), with the exception of anomalous sample 7, are grouped together (Cluster 1 in Fig. 2). Samples taken inside or downstream of Madrid, down to the confluence of the Manzanares with the Jarama River, on the other hand, are divided in two groups (clusters 2 and 3 in Fig. 2). The reason for this separation is that samples 15, 16 and 18, which make up Cluster 3, represent the highest contents in calcium carbonate, with $\mathrm{Ca}$ concentrations at least twice as high as those found in the samples included in Cluster 2. (The fact that sample 7 is included in this second cluster probably reflects its anomalous nature (see discussion above) and dissimilarity with the "natural" samples upstream from Madrid (Cluster 1), rather than an

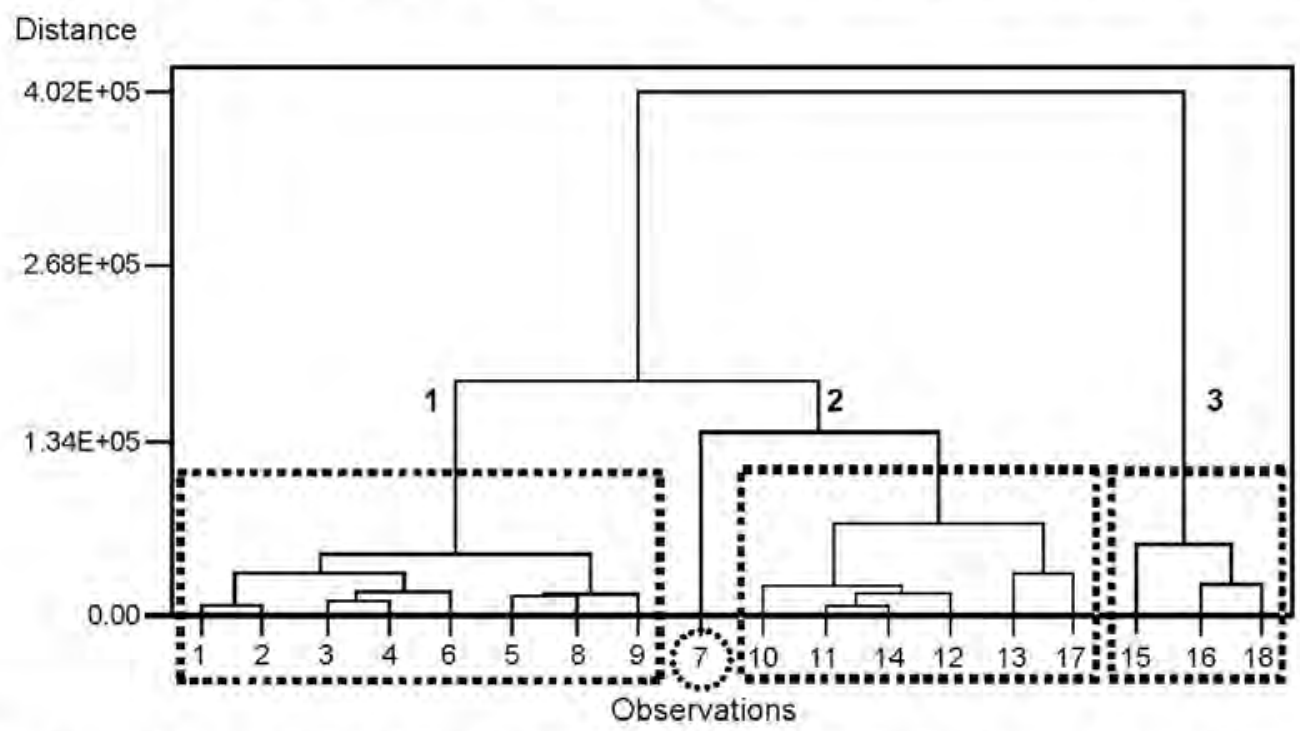

Fig. 2. Cluster analysis of the results $\left(\mu \mathrm{g} \mathrm{g}{ }^{-1}\right.$ ) of the "total" digestion ( $\mathrm{HNO}_{3}, \mathrm{HClO}_{4}, \mathrm{HF}$ ). (Distance measure: Manliattan; linkage method: Ward). Rectangles mark the three clusters considered in the analysis (Cluster 1: Samples taken upstream from Madrid; Cluster 2: Samples taken inside or downstream of Madrid, with $[\mathrm{Ca}]<32000 \mu \mathrm{g} \mathrm{g}{ }^{-1}$. Cluster $3 \div$ Samples taken inside or downstream of Madrid, with $[\mathrm{Ca}]>70000 \mu \mathrm{gg} \mathrm{g}^{-1}$ ). 
Table 5

Centroids (arithmetic mean, in $\mu \mathrm{g} \mathrm{g}^{-1}$ ) of three clusters resulting from a $\mathrm{K}$-means cluster analysis excluding $\mathrm{Ca}$

\begin{tabular}{|c|c|c|c|c|}
\hline \multirow[t]{2}{*}{ Element } & \multicolumn{4}{|l|}{ Centroids } \\
\hline & $\begin{array}{l}\text { Cluster 1- } \\
\text { "natural" } \\
\text { Samples 1-9 } \\
\text { (except S7) }\end{array}$ & $\begin{array}{l}\text { Cluster } 2 \\
\text { Sample } 7\end{array}$ & $\begin{array}{l}\text { Cluster 3- } \\
\text { "urban" } \\
\text { Samples } \\
10-18 \\
\end{array}$ & $\begin{array}{l}\text { Enrichment } \\
\text { Factor (\%) } \\
\text { Cluster 3/ } \\
\text { Cluster 1 } \\
\end{array}$ \\
\hline $\mathrm{Ag}$ & 1.5 & 2 & 6.6 & 452 \\
\hline $\mathrm{Al}$ & 86525 & 61900 & 66577 & 77 \\
\hline As & 17 & 57 & 24 & 143 \\
\hline $\mathrm{Ba}$ & 360 & 29 & 284 & 79 \\
\hline $\mathrm{Be}$ & 6.4 & 6 & 4.7 & 73 \\
\hline $\mathrm{Ce}$ & 154 & 136 & 129 & 84 \\
\hline $\mathrm{Co}$ & 5.1 & 9 & 6.4 & 126 \\
\hline $\mathrm{Cr}$ & 27 & 33 & 48 & 175 \\
\hline $\mathrm{Cu}$ & 27 & 144 & 101 & 367 \\
\hline $\mathrm{Fe}$ & 22137 & 90800 & 25956 & 117 \\
\hline $\mathrm{Hg}$ & 0.164 & 0.076 & 0.805 & 490 \\
\hline $\mathrm{K}$ & 26562 & 21100 & 27967 & 105 \\
\hline $\mathrm{La}$ & 76 & 66 & 70 & 92 \\
\hline $\mathrm{Mg}$ & 5262 & 7000 & 8989 & 171 \\
\hline $\mathrm{Mn}$ & 489 & 1276 & 386 & 79 \\
\hline $\mathrm{Na}$ & 16062 & 11700 & 12844 & 80 \\
\hline $\mathrm{Ni}$ & 14 & 33 & 22 & 160 \\
\hline $\mathrm{P}$ & 833 & 1297 & 1233 & 148 \\
\hline $\mathrm{Pb}$ & 75 & 207 & 146 & 195 \\
\hline $\mathrm{Ti}$ & 2412 & 2200 & 2867 & 119 \\
\hline V & 28 & 29 & 34 & 119 \\
\hline $\mathrm{Y}$ & 31 & 26 & 25 & 81 \\
\hline $\mathrm{Zn}$ & 87 & 182 & 294 & 336 \\
\hline
\end{tabular}

intrinsic proximity to the geochemical nature of the "urban" samples in Cluster 2). If the influence of $\mathrm{Ca}$ content is removed by excluding this variable from a $\mathrm{K}$-means Cluster analysis in three groups, all samples collected within Madrid's area of influence (samples 10-18) are reunited in one single, "urban" group (Cluster 3), all samples taken upstream of Madrid, and thus unaffected by significant urban discharges, remain grouped in the "natural" Cluster 1, and pyrite-rich sample 7 forms a group-Cluster 2-of its own (Table 5). The dissimilar nature of the sediments in the "urban" and "natural" reaches is manifested in the widely different average concentrations of anthropogenic elements for both groups (enrichment factors in "urban" relative to "natural": $\mathrm{Ag}, 450 \%$; $\mathrm{Cr}, 175 \% ; \mathrm{Cu}, 365 \% ; \mathrm{Pb}, 195 \%$; and $\mathrm{Zn}$, $340 \%$ ). In contrast, most major elements ( $\mathrm{Fe}, \mathrm{K}, \mathrm{Na}$, Ti) and essentially geogenic trace elements $(\mathrm{Ce}, \mathrm{La}$, Y) show fairly uniform concentrations in both clusters, or slightly higher in the "natural" group.
As opposed to the classification derived from the Cluster Analysis, which is based on the varying degree of urban influence on the sediments, the concentration of $\mathrm{Al}, \mathrm{Ca}$ and $\mathrm{Mg}$ are directly related to the lithology along each section of the Manzanares basin. In the northern, upper part of its basin the river runs through a granitic mountainous area until it meets the alluvial materials (gravel, sand and silt) to the north of Madrid and south of the mountain range. The silicate nature of these geologic formations is reflected in high $\mathrm{Al}$ and relatively low (when compared to the carbonate materials found further south) $\mathrm{Ca}$ and $\mathrm{Mg}$ concentrations in the sediments $(86500,6150$, and $5260 \mu \mathrm{g} \mathrm{g}^{-1}$, respectively). As the river exits the culverted reach within the boundaries of Madrid, it flows through a landscape of limestone and gypsumrich marl. Consequently, the sediments to the southeast of the city present higher $\mathrm{Ca}$ and $\mathrm{Mg}$ contents (38500 and $9000 \mathrm{\mu g} \mathrm{g}^{-1}$, respectively) and lower levels of $\mathrm{Al}\left(66500 \mu \mathrm{g} \mathrm{g}^{-1}\right)$.

These influences, anthropogenic (or "urban") and geogenic (or "natural") are underscored by the results of a Factor Analysis for the "total" digest, shown in Table 6. Four factors explain most of the variability $(82 \%)$ of the data. The first factor seems to reflect the "urban" contribution to the elemental composition of the sediment. It comprises the variables $\mathrm{Ag}, \mathrm{Cr}, \mathrm{Cu}, \mathrm{Pb}$

Table 6

Factor Analysis of the results ( $\mu \mathrm{g} \mathrm{g}^{-1}$ ) of the "total" digestion $\left(\mathrm{HNO}_{3}, \mathrm{HClO}_{4}, \mathrm{HF}\right.$ ) for 16 variables (factor loadings $<0.3$ have been omitted for clarity)

\begin{tabular}{lccccc}
\hline Variable & Factor 1 & Factor 2 & Factor 3 & Factor 4 & Communality \\
\hline $\mathrm{Cr}$ & 0.938 & & & & 0.882 \\
$\mathrm{Cu}$ & 0.924 & & & & 0.959 \\
$\mathrm{Ag}$ & 0.913 & & & & 0.949 \\
$\mathrm{~Pb}$ & 0.891 & & & & 0.870 \\
$\mathrm{Zn}$ & 0.886 & 0.400 & & & 0.945 \\
$\mathrm{Mg}$ & 0.740 & 0.551 & & & 0.855 \\
$\mathrm{Ca}$ & & 0.855 & & & 0.827 \\
$\mathrm{Na}$ & & -0.821 & & & 0.849 \\
$\mathrm{Al}$ & -0.439 & -0.690 & & & 0.755 \\
$\mathrm{~K}$ & & 0.337 & & & 0.171 \\
$\mathrm{Mn}$ & & & 0.952 & & 0.957 \\
$\mathrm{Fe}$ & & & 0.914 & & 0.898 \\
$\mathrm{As}$ & 0.308 & & 0.704 & & 0.632 \\
$\mathrm{La}$ & & & & 0.995 & 0.999 \\
$\mathrm{Ce}$ & & & & 0.972 & 0.992 \\
$\mathrm{Y}$ & & -0.564 & & 0.660 & 0.794 \\
\% variance & 32.5 & 18.4 & 16.4 & 16.1 & 83.3 \\
\hline
\end{tabular}

Extraction Method: Maximum Likelihood; Rotation: Varimax. 
and $\mathrm{Zn}$ that exhibit low concentrations before Madrid and much higher ones within and after the city. Enrichment in this same suite of elements has been used in earlier studies to measure the degree of urban disturbance of a soil (De Miguel et al., 1998). The same conclusion seems to apply to river sediments (Birch et al., 2001; Ridgway et al., 2003), a fact that appears to confirm the hypothesis that the elemental combination $\mathrm{Ag}-\mathrm{Cr}-\mathrm{Cu}-\mathrm{Pb}-\mathrm{Zn}$ is a characteristic marker of the particulate matter generated in and circulating between the different geochemical spheres in urban environments (De Miguel et al., 1999).

The second factor positively groups $\mathrm{Ca}$ and $\mathrm{Mg}$, on the one hand, and negatively $\mathrm{Al}$ and $\mathrm{Na}$. This factor reveals the nature (carbonate vs. silicate) of the geological material that gives rise to the river sediments. As would be expected, the lowest scores for this factor correspond to samples collected in the granite, sand and silt areas in the north, and they increase towards the south-east where the river flows through carbonate materials. The third factor (Fe-Mn-As) seems to be a manifestation of the process of trace element adsorption by $\mathrm{Fe}$ and $\mathrm{Mn}$ hydrous oxides. If this assumption were correct, then As would be preferentially retained in the sediment bound to the oxy-hydroxide fraction and would show a higher affinity for this fraction than the other trace elements considered. However, this factor disappears from the results when sample 7 (pyrite-rich core) is excluded from the analysis. The high correlation between As and $\mathrm{Fe}-\mathrm{Mn}$ that gives rise to the third factor seems to be a statistical artifact related to the anomalous nature of sample 7 and not to a real, underlying phenomenon. Lastly, the fourth factor appears to represent a natural matrix of the sediment that remains fairly constant throughout the whole length of the river, unaffected by changes in lithology or in intensity of urban discharges, and characterised by $\mathrm{La}, \mathrm{Ce}$ and $\mathrm{Y}$.

The "weak" digestion protocol is assumed to dissolve the fraction of trace elements bound to the carbonate matrix of the sediments, as well as that associated with soluble minerals and exchange sites on clay surfaces (Tessier et al., 1979). The percentage of the "total" metal content extracted in the "weak" digest depends strongly on the proportion of calcite in the sediment and, for the same amount of calcite, varies greatly for the different metals analysed. The influence of the amount of calcium carbonate in the sample on the fraction of metal recovered is particularly significant for $\mathrm{Zn}$ (and, to a lesser extent, $\mathrm{Cu}$ ). In the samples collected from the northern reach of the river, where calcite is essentially absent from the sediment, the amount of $\mathrm{Zn}$ extracted does not exceed $10 \%$ of the "total" $(15 \%$ for $\mathrm{Cu})$-except in sample 5 , where it reaches $19 \%$. However, in the final section of the Manzanares, where carbonates are most abundant, recoveries reach $75 \%$ for $\mathrm{Zn}$ and $54 \%$ for $\mathrm{Cu}$.

These results seem to indicate that two different influences on the geochemical constitution of the sediment become superimposed in the samples taken within or downstream of the city. Firstly, these sediments can reach high natural calcite contents (up to $20 \%$ ), as shown in the results of X-ray diffraction analyses (Table 3). Secondly, they are exposed to effluents from the WWT plants and to uncontrolled discharges of urban runoff. As a result, these sediment samples are enriched in all "urban" elements (i.e. Cr, $\mathrm{Cu}, \mathrm{Pb}$ and $\mathrm{Zn}$ ) but particularly in elements like $\mathrm{Zn}$, and to a lesser extent $\mathrm{Cu}$, which have a higher tendency to sorb onto calcite. The interaction of divalent metals with calcite has been extensively investigated (Crockett and Winchester, 1966; Kitano et al., 1976; McBride, 1979, 1980; Franklin and Morse, 1982, 1983; Kornicker et al., 1985; Davis et al., 1987, Zachara et al., 1988; Tesoriero and Pankow, 1996; Parkman et al., 1998). As a result, several mechanisms have been proposed to explain the retention of these elements by calcite surfaces, i.e. adsorption, ion exchange, surface complexation, solid solution precipitation and pure-phase precipitation, depending on factors such as ionic radii and solvation energies of the cations, concentration of metals in solution, recrystallization rates of calcite, etc. In the specific case of $\mathrm{Zn}$, Zachara et al. (1988) concluded that adsorption onto calcite mainly occurs through exchange of $\mathrm{Zn}^{2+}$ and $\mathrm{ZnOH}^{+}$with $\mathrm{Ca}^{2+}$ in a hydrated layer adsorbed to the calcite surface, and that the surface complex thus formed had a marked covalent character. Thus, the considerable desorption of $\mathrm{Zn}$ from the carbonate surface at moderately low $\mathrm{pH}$ values observed in our work is attributed by Zachara et al. (1988) to the reversibility of the sorption process in the presence of $\mathrm{Ca}^{2+}$ which increases in concentration as the $\mathrm{pH}$ of the $\mathrm{CaCO}_{3 \text { (ai) }}$ solution is lowered. This fact indicates that $\mathrm{Zn}$ and $\mathrm{Cu}$ are the two elements more susceptible to be remobilised from the sediment 
and incorporated into the aqueous phase, and that this process is most likely to occur precisely where the highest concentrations of both elements are found, in the southern stretch of the river after it crosses Madrid.

\section{Conclusions}

The River Manzanares, which in years of low precipitation can carry up to $60 \%$ of urban water, constitutes an interesting example of an urban river with a strong anthropic control on its geochemical and hydrodynamic behaviour. Trace element concentrations in the sediments of the Manzanares show local lithological influences superimposed on urban inputs, in the form of treated urban wastewater and uncontrolled discharges of street runoff. The geochemical signature of each of these influences can be determined by means of a K-means Cluster Analysis of the samples and a Factor Analysis of "total" (i.e. $\mathrm{HNO}_{3}+\mathrm{HClO}_{4}+\mathrm{HF}$ extraction) elemental concentrations in the sediment. The "urban" component of the trace element load is characterised by the $\mathrm{Ag}-\mathrm{Cr}-\mathrm{Cu}-$ $\mathrm{Pb}-\mathrm{Zn}$ association, individual elements of which show enrichment factors between $200 \%$ and $450 \%$ after the river enters the city of Madrid. This finding is consistent with earlier studies which suggested that this same suite of elements characterises particulate matter of urban origin and serves as a fingerprint of urban disturbance in soils.

On the other hand, the "natural" component appears to be separated into two factors. Ce, La and Y show fairly constant concentrations all along the river and seem to reveal a "natural" background which is not greatly affected by changes in lithology. These changes, however, are clearly reflected in the concentration of $\mathrm{Ca}$ and $\mathrm{Mg}$, on one side, and $\mathrm{Al}$ and $\mathrm{Na}$, on the other, which vary strongly as the mineral matrix of the sediment changes from carbonate to silicate.

Although the "total" concentration of trace elements in the sediments of the Manzanares are similar to those found in other urban rivers, toxicological threshold levels for most of these elements are exceeded after the river crosses Madrid, a fact that raises concerns about latent adverse effects on aquatic ecosystems housed in the sediments of this stretch of the river.

The potential mobility and bioavailability of trace elements in the sediments of the Manzanares were evaluated through an $\mathrm{NaOHAc}+\mathrm{HOAc}$ extraction. The highest extraction rates corresponded to $\mathrm{Zn}$ and, to a lesser extent, $\mathrm{Cu}$. Both divalent cations show a high affinity for carbonate materials in the sediment and are easily displaced from the solid matrix and transferred to the aqueous phase. Since the concentration of $\mathrm{Ca}$ and $\mathrm{Mg}$ carbonate greatly increases in the sediment after the river crosses Madrid where it receives an important input of $\mathrm{Cu}$ and $\mathrm{Zn}$, the highest potential for remobilisation and negative environmental impact is expected precisely along this stretch of the river, south of Madrid.

\section{Acknowledgements}

The authors would like to express their gratitude to the British and Spanish Ministries of Science for their financial support through the Acciones Integradas grant HB 1999-0029. The authors are also deeply indebted to the Spanish Geological Survey (IGME) for the ICP-AES, Cold Vapour-AAS and XRD analyses of the Manzanares samples.

\section{References}

Alarcón P. Aplicación de técnicas espectrofotométricas al análisis del agua y sedimentos del río Henares. Bol Geol Min 1990;101-5:185-93 [in Spanish].

Birch G, Siaka M, Owens C. The source of anthropogenic heavy metals in fluvial sediments of a rural catchment: Coxs River, Australia. Water Air Soil Pollut 2001;126:13-35.

Crockett JH, Winchester JW. Co-precipitation of zinc with calcium carbonate. Geochim Cosmochim Acta 1966;30:1093-109.

Davis JA, Fuller CC, Cook AD. A model for trace metal sorption processes at the calcite surface: adsorption of $\mathrm{Cd}^{2+}$ and subsequent solid solution formation. Geochim Cosmochim Acta 1987;51:1477-90.

De Miguel E, Jiménez de Grado M, Llamas JF, Martín-Dorado A, Mazadiego LF. The overlooked contribution of compost application to the trace element load in the urban soil of Madrid. Sci Total Environ 1998;215:113-22.

De Miguel E, Llamas JF, Chacón E, Mazadiego LF. Sources and pathways of trace elements in urban environments: a multielemental qualitative approach. Sci Total Environ 1999;235: $355-7$.

Environment Canada, 2002. Canadian Environmental Quality Guidelines: Summary Table. http://www.ccme.ca/assets/pdf/ el_06.pdf.

Epstein MS, Diamondstone BI, Gills TE. A new river sediment standard reference material. Talanta 1989;36:141-50. 
Estèbe A, Boudries H, Mouchel JM, Thevenot DR. Urban nunoff impacts on particulate metal and hydrocarbon concentrations in river Seine. Water Sci Technol 1997;36:185 -93.

Foster IDL, Charlesworth SM. Heavy metals in the hydrological cycle: trends and explanations. Hydrol Process 1996;10:227-61.

Foster IDL, Charlesworth SM, Proffitt SB. Sediment-associated heavy metal distribution in urban fluvial and limnic systems; a case study of the River Sowe, UK. Arch Hydrobiol Spec Issues Adv Limnol 1996;47:537 -45.

Franklin ML, Morse JW. The interaction of copper with the surface of calcite. Ocean Sci Eng 1982;7:147-74.

Franklin ML. Morse JW. The interaction of manganese (U) with the surface of calcite in dilute solutions and seawater. Mar Chem $1983 ; 12: 241-54$.

Gundacker C. Comparison of heavy metal bioaccumulation in freshwater molluses of urban river habitats in Viemna. Environ Pollut 2000;110:6L-71.

Jones, D.S., Sutter II, G.W., Hull, R.N.y 1997. Toxicological Benchmarks for Screening Contaminants of Potential Concern for Effects on Sediment-Associated Biota: 1997 Revision. ES/ ER/TM-95/R4. Oak Ridge National Laboratory, prepared for the US Department of Energy. http://riskassessment.ornl.gov/ documents/tm95 4 .pdf.

Kitanó Y, Kanamori N, Yoshioka S. Adsorption of zinc and copper ions on calcite and aragonite and its influence on the transformation of aragonite to calcite. Geochem J 1976;10:175-9.

Kornicker WA, Morse JW, Damasceno RN. The chemistry of $\mathrm{Co}^{2+}$ interaction with calcite and aragonite surfaces. Chem Geol 1995;53:229-36.

McBride MB. Chemisorption and precipitation of $\mathrm{Mn}^{2-}$ at $\mathrm{CaCO}_{3}$ surfaces. Soil Sci Soc Am J 1979;43:693-8.

McBride MB. Chemisorption of $\mathrm{Cd}^{2+}$ on calcite surfaces. Soil Sci Soc Am J 1980;44:26-8.

Minissi S, Caccese D, Passafiume F, Grella A, Ciccotti E, Rizzoni M. Mutagenicity (micronucleus test in Vicia Faba root tips), polycyclic aromatic hydrocarbons and heavy metal content of sediments collected in Tiber river and its tributaries within the urban area of Rome. Mutat Res, Genet Toxicol Environ 1998;420:77-84.

Ontario Ministry of Environment and Energy, 1998. Guideline for use at contaminated sites in Ontario. Appendix 2: Soil, groundwater and sediment criteria. http://www.ene.gov,on.ca/ envision/gp/3161e01 appendix.pdf.

Parkman RH, Charnock JM, Livens FR, Vaughan D. A study of the interaction of strontium ions in aqueous solution with the surfaces of calcite and kaolinite. Geochim Cosmochim Acta 1998;62:1481-92.

Ridgway J, Breward N, Langston WJ, Lister R, Rees JG, Rowlatt SM. Distinguishing between natural and anthropogenic sources of metals entering the Irish Sea. Appl Geochem 2003;18:283-309.

Sutherland RA. A comparison of geochemical information obtained from two fluvial bed sediment fractions. Environ Geol 2000;39:330 - 41.

Tesoriero A.J. Pankow JF. Solid solution partitioning of $\mathrm{Sr}^{2+}, \mathrm{Ba}^{2+}$, and $\mathrm{Cd}^{2+}$ to calcite. Geochim Cosmochim Acta 1996;60: $1053-63$.

Tessier A, Campbell PGC, Bisson M. Sequential extraction procedure for the speciation of particulate trace metals. Anal Chem 1979;51:844-51.

UN. Population Division (UNPD), 1996. Urban and Rural Areas 1950-2030 (The 1996 Revision). UNPD, New York, on diskette.

U.N. Population Division (UNPD), 2001. World Urbanization Prospects: The 1999 Revision. http://www.undp.org/popin/ wdtrends/wdirends.him.

US Environmental Protection Agency, 1994. Method 7471A. Mercury in Solid or Semisolid Waste (Manual Cold-Vapor Technique), http:/www.epa.gov/SW-846/7471a.pdf.

US Environmental Protection Agency, 1999. Screening level ecological risk assessment protocol for hazardous waste combustion facilities, Volume 3. Appendix E: Toxicity Reference Values. EPA 530-D99-001C. htip://www.epa.gov/ epaoswer/hazwaste/combusteco-risk/volume3/appx-e,pdf.

Vignati D, Pardos M, Diserens J, Ugazio G, Thomas R, Dominik J. Characterisation of bed sediments and suspension of the river $\mathrm{Po}$ (Italy) during normal and high flow conditions. Water Res $2003 ; 37: 2847-64$.

Walker WJ, McNutt RP, Maslanka CA. The potential contribution of urban runoff to surface sediments of the Passaic river: sources and chemical characteristics. Chemosphere 1999:38:363-77.

Widianarko B, Verwij RA, Van Gestel CAM, Van Straalen NM. Spatial distribution of trace metals in sediments from urban streams of Semarang, Central Java, Indonesia. Ecotoxicol Environ Saf 2000;46:95-100.

World Development Indicators 2000. Washington DC: The World Bank; 2000.

Zachara JM, Kittrick JA, Harsh JB. The mechanism of $\mathrm{Zn}^{2+}$ adsorption on calcite. Geochim Cosmochim Acta 1988;52: $2281-91$. 